(C) 2022, The Authors. Published by Elsevier Inc. and Fass Inc. on behalf of the American Dairy Science Association ${ }^{\circledR}$. This is an open access article under the CC BY license (http://creativecommons.org/licenses/by/4.0/).

\title{
Dairy farmers' perspectives on providing cow-calf contact in the pasture-based systems of New Zealand
}

\author{
Heather W. Neave, ${ }^{1 *} \dagger \odot$ Christine L. Sumner, ${ }^{2} \odot$ Roxanne J. T. Henwood, ${ }^{3} \odot$ Gosia Zobel, ${ }^{1} \odot$ Katie Saunders, ${ }^{4}$ \\ Helen Thoday, ${ }^{4}$ Trevor Watson, ${ }^{1}$ and James R. Webster ${ }^{5} \odot$ \\ ${ }^{1}$ Animal Behaviour and Welfare, Ruakura Research Centre, AgResearch Ltd., 10 Bisley Rd, Hamilton 3214, New Zealand \\ ${ }^{2}$ Royal New Zealand Society for the Prevention of Cruelty to Animals, 3047 Great North Road, Auckland 0600, New Zealand \\ ${ }^{3}$ People and Agriculture, Lincoln Research Centre, AgResearch Ltd., 1365 Springs Rd, Lincoln 7674, New Zealand \\ ${ }^{4}$ DairyNZ Ltd., Private Bag 3221, Hamilton 3240, New Zealand \\ ${ }^{5}$ Animal Ethics Office, Ruakura Research Centre, AgResearch Ltd., 10 Bisley Rd, Private Bag 3123, Hamilton 3214, New Zealand
}

\begin{abstract}
Separation of the cow and calf shortly after birth is a common practice on commercial dairy farms around the world, but there are emerging concerns about this practice among citizens and other stakeholders. Continuous improvement of on-farm management practices in collaboration with dairy sector stakeholders increases the likelihood that farming systems evolve in a way that is consistent with societal expectations. Few commercial dairy farms provide extended cow-calf contact, and there is little understanding of how dairy farmers view this practice. This study examined the views of New Zealand dairy farmers toward providing cow-calf contact, particularly the barriers to adopting such a system in a seasonal-calving pasture-based dairy system. Standard farm practice in New Zealand is to remove the calf from the cow around $24 \mathrm{~h}$ (but could be up to $48 \mathrm{~h}$ ) after birth. These conventional farmers $(\mathrm{n}=63)$ were randomly selected from the database of all dairy farmers in New Zealand and telephone-interviewed using a semistructured interview format. Their responses to questions about providing cow-calf contact (defined as contact beyond the standard practice of 48 h) were analyzed using thematic analysis. Three major themes of concern were identified by these farmers about providing cow-calf contact as follows: (1) poor animal welfare, especially the risk of mastitis in the dam, inadequate colostrum for the calf, increased stress from delayed separation, and lack of shelter for calves while outdoors with the cow; (2) increased labor and stress on staff; and (3) system-level changes required, including infrastructure and herd management. Many
\end{abstract}

Received July 21, 2021.

Accepted September 8, 2021.

*Corresponding author: heather.neave@agresearch.co.nz

†Current address: Department of Animal Science, Aarhus University, Tjele 8830, Denmark. of these concerns stemmed from challenges related to the nature of large-scale seasonal-calving pasture-based dairy systems, where a large number of calves are born in a short period of time and may be exposed to inclement weather in late winter in some areas. Several small-scale farmers $(\mathrm{n}=4)$ providing cow-calf contact for longer than standard practice of $48 \mathrm{~h}$ were also interviewed; all permitted contact for at least $4 \mathrm{wk}$. These farmers also felt that animal welfare and health were important, and that this was promoted in their cowcalf contact systems. Concerns about colostrum and mastitis, for example, were not raised by these farmers, but they did agree that additional infrastructure and shelter were important considerations for cow-calf contact systems. Some conventional farmers expressed cognitive dissonance in that they theoretically preferred cow-calf contact but could not see it being realistic or practical to implement. Farmers currently providing longer cow-calf contact may be a useful resource for better understanding of how practical and economical cow-calf contact systems could be adopted on commercial pastoral dairy farms.

Key words: animal welfare, farmer attitude, cow-calf separation, maternal contact, sustainability

\section{INTRODUCTION}

Concern from the public is growing about where their food comes from, and welfare of farmed animals is a particular focus. In dairy farming, concerns have centered around management practices that induce pain, such as dehorning of dairy calves (Robbins et al., 2015), or that limit expression of natural behavior, such as limited or no access to pasture (Schuppli et al., 2014; see review by Placzek et al., 2021). Providing reasons for why these practices occur on farms does not appear to resolve these concerns (Ventura et al., 2016; Cardoso et al., 2017). In other livestock sectors, public concern for farm practices has resulted in food retailers setting 
standards for their supply farms, such as the sourcing of only cage-free eggs for McDonald's in the United States (Shields et al., 2017). Other countries have introduced national legislation governing how animals must be cared for, such as a ban on tail docking of piglets in Sweden and Norway (Veissier et al., 2008) and a ban on caged laying hens across the European Union (Scrinis et al., 2017). Traditionally, dairy farming has upheld a relatively good image in the public eye (Boogaard et al., 2011), but this may be because the public generally has little knowledge about dairy farming (Ellis et al., 2009). The public's lack of insight into routine dairy cattle management practices poses a risk to the sustainability of the industry if the practices do not align with societal values, especially regarding management that affects animal welfare (von Keyserlingk et al., 2013; Weary et al., 2016). Given that public opinion can become a major driver for industry changes, there is a need for the dairy industry to be engaged with all stakeholders, promoting transparency and proactive future planning in sustainable dairying.

Separating the cow and calf immediately or shortly after birth is routinely practiced on dairy farms around the world but may be viewed unfavorably, depending on the stakeholder. Long-standing reasons supporting separation include protecting the health of the calf and cow, reducing the stress of later separation after bonding, ensuring colostrum intake by the calf, and increasing saleable milk from the cow (Sumner and von Keyserlingk, 2018; Beaver et al., 2019). The public in many countries are largely unaware that calves are commonly removed from the cow, but when presented with information, they show little support for it (Canada and United States: Ventura et al., 2013, 2016; Germany: Busch et al., 2017; Brazil: Cardoso et al., 2017; Hötzel et al., 2017; Netherlands: Boogaard et al., 2011). The main objection to cow-calf separation is its unnaturalness; the public typically consider farming systems to have good animal welfare if they are perceived to be natural (see reviews by Clark et al., 2016; Placzek et al., 2021).

In some European countries, some farmers now provide extended cow-calf contact, partly in response to public concern about cow-calf separation (Vaarst et al., 2020). In other countries, such as New Zealand, the issue of cow-calf separation has largely remained out of the public spotlight, although an industry-led survey of the public suggests that this is an area of concern $(\mathrm{H}$. Thoday, DairyNZ Ltd., unpublished data). It is critical to gain insight into the beliefs of farmers regarding this practice. There is little information on how dairy farmers view cow-calf separation in comparison with the provision of cow-calf contact (with 2 exceptions: Ventura et al., 2013; Pempek et al., 2017); no studies have focused on pastoral-based dairy systems, which is relevant as they are likely to present different challenges compared with housed dairy systems. For example, New Zealand dairy farming uses year-round rotational grazing of pasture for dairy cows, and seasonal calving in late winter also occurs outdoors. The outdoor calving area is typically checked 4 to 6 times per day, and calves are moved into a sheltered group pen around 24 $\mathrm{h}$ after birth and fed colostrum. Cows are milked by walking varying distances from the pasture to the milking parlor, and calves are reared in the indoor group pen away from the cows with a separate pasture area. The average herd size on New Zealand dairy farms is 440 cows (LIC and DairyNZ, 2020), which is larger than average herd sizes of other major milk-producing countries predominantly with indoor-housed dairy cattle [e.g., average 175 cows/herd in the United States (MacDonald et al., 2020) and less than 150 cows/herd in the European Union (Nehring et al., 2016)].

Given the contrast in seasonal-calving and pasturebased versus indoor-housing dairy systems, it is necessary to understand the perspectives of New Zealand dairy farmers regarding provision of cow-calf contact and how they would be affected if changes to calf rearing were required in the future. The objective of this study was to examine the perspectives of New Zealand dairy farmers toward providing cow-calf contact, and to describe the cow-calf contact systems and perspectives of farmers that are already rearing calves with cows.

\section{MATERIALS AND METHODS}

\section{Study Design and Reflexivity Statement}

We were interested in better understanding the views of New Zealand dairy farmers as they related to the practice of separating cows and calves after birth. We sought to learn about their attitudes, values, and beliefs, and how these factors relate to decision-making on their own farms currently and in the future. This work was conducted by employees of AgResearch Ltd. (authors H.N., R.H., G.Z., J.W.), a Crown Research Institute that operates independently of the New Zealand dairy sector. This work was commissioned by employees of DairyNZ Ltd. (authors H.T., K.S), the industry body representing all 11,179 dairy farms in New Zealand. All authors were or became aware of the increasing global concern around the practice of cow-calf separation, and began this work with the view that the New Zealand dairy industry will need models, exemplars, and support if market demands or government legislation were to require provision of cow-calf contact in the future. The research team members held a range of experiences in the New Zealand dairy industry (experienced: H.T., 
K.S., J.W.; moderate: H.N., C.S., G.Z.; limited: R.H.), were native to different countries and thus different dairying systems (New Zealand: R.H., K.S., J.W.; Canada: H.N., G.Z.; United States: C.S.; United Kingdom: H.T.), and served the dairy industry in a range of roles including animal behavior and welfare scientists (H.N., C.S., G.Z., J.W), industry representatives (H.T., K.S.), and qualitative researchers (C.S., R.H.). None of the authors were currently practicing dairy farming. The individual who conducted the interviews (T.W.) was male and employed by AgResearch Ltd., native to New Zealand, and had extensive experience with the dairy industry and previously managed several farms; this likely aided in creating a comfortable conversation and interview between T.W. and the farmer. However, T.W. was given no information on the immediate purpose of the study before interviewing farmers. We acknowledged that dairy farmers often experience externally-driven pressure to change farm practices in various areas (such as environmental concerns), so this may have influenced their attitudes toward adoption of another value-laden management practice such as providing extended cow-calf contact. All authors may similarly have been affected by these attitudes.

\section{Participant Recruitment}

Ethical approval of low-risk, non-health research is not legally required in New Zealand. The present study was peer reviewed and assessed as compliant with the AgResearch People and Agriculture Team ethical guidelines for research $(\# 7 / 20)$. Semistructured phone interviews were conducted from June to July 2020, to understand New Zealand farmers' attitudes, beliefs, and experiences related to providing cow-calf contact. Little is known about farmers' views on cow-calf separation; therefore, semistructured interviews were used to ensure depth and richness of responses to our questions. Telephone interviews were chosen because this made it feasible to reach the targeted number of people and broad geographic spread. To help ensure an unbiased sample of New Zealand farmers were selected, a contact list of 122 farmers was generated, with an equal number from North and South Islands (because farm practices are known to differ between these locations, primarily related to climate, and farm sizes are larger on the South Island) and ownership categories (because this could affect attitudes toward management practices). Information on age, sex, and farm experience were not available in the database to allow us to balance for these factors, but we collected this information in the interviews. The list was randomly generated from the DairyNZ database comprising all 11,179 dairy farms in New Zealand (DairyNZ et al., 2017). Ownership categories characteristic of New Zealand dairy farming reflected the structure of labor and monetary contribution to the farm by an individual, ranging from least monetary ownership of land or animals (contract milker, farm manager) to part ownership of land or animals (share milker, share owner) to full ownership (farm owner). Farmers on the list received an introductory email, followed by an initial telephone call from a single research team member (T.W.) to set up a date and time for a telephone interview. In the initial phone call, all farmers agreed to participate. Farmers that stated they removed calves from the cows within $48 \mathrm{~h}$ after birth were considered "conventional farmers" $(\mathrm{n}=63)$, with this number determined before the study began as being sufficient to provide data saturation (i.e., further interviews would not yield any new information; see Saunders et al., 2018).

Consistent with our aim of identifying enablers to practice, we included farmers who practiced cow-calf contact to provide insight into this practice. Farmers that stated calves remained with the cows for longer than standard practice (defined as beyond $48 \mathrm{~h}$ ) were considered "cow-calf contact farmers" $(\mathrm{n}=4)$. Fewer than 10 farmers in New Zealand (identified through existing contacts and dairy industry knowledge) were known to practice cow-calf contact, indicating this is an uncommon practice for rearing dairy calves. We wanted to minimize bias of understanding calf rearing from the normal practitioner's point of view; therefore, it was important to include the viewpoint of farmers who practice cow-calf contact. We are confident we reached data saturation within each interview with cow-calf contact farmers to have provided adequate comparison to the conventional practice. All cow-calf contact farmers that authors were aware of at the time of the survey were contacted in the same manner as the conventional farmers, of which 4 responded and agreed to be interviewed.

\section{Interview Design}

Before the interviews, farmers were informed that participation was voluntary and that answers would be anonymized. Interviews were one-on-one, semistructured conversations following a prescribed list of questions and prompts (see Supplemental Material; https://doi.org/10.17632/4rj6z2wvyb.1) and were audio recorded; the interview questions were piloted with 2 farmers who did not participate in the final study. To encourage farmer engagement, each call began with a casual conversation to establish rapport. Then, the farmers were informed that the survey aimed to un- 
derstand their viewpoints about different calf-rearing practices. Most of the interviews lasted for 10 to 20 min, but a smaller number of interviews were longer, up to $48 \mathrm{~min}$.

The first part of the interview captured demographic information (length of time in dairying, role on farm, region, farm size, farm system), as well as descriptive information about the calf-management system used (place of calving, length of time cows and calves are left together, colostrum management). Conventional farmers were asked about the benefits, drawbacks, and rationale for separating cows and calves within $48 \mathrm{~h}$ after birth. They were also asked whether they had considered providing cow-calf contact beyond standard practice of $48 \mathrm{~h}$, what concerns they had about cow-calf contact systems, and how cow-calf contact may affect animal health. Finally, they were asked about their ideal system for calf management, and the interview closed with 2 brief demographic questions (age, education level). Farmers that stated calves remained with the cows for longer than standard practice (beyond 48 h) were considered "cow-calf contact farmers." These farmers were asked for the same demographic information as conventional farmers, and then additionally asked to describe their calf-management system, including colostrum management, management of calves during milking, and access to shelter. Further questions covered the reasons for and against cow-calf contact, and effects of cow-calf contact on cow and calf health. Final questions were the same as for the conventional farmers (ideal system for calf management, demographic questions).

\section{Thematic Analysis}

Interview audio recordings were transcribed by a professional external to the research group, then analyzed for key themes using NVivo 12 Plus (QSR International). Thematic analysis was used to first identify codes (interpretive labels applied to the data), broader categories that these codes were organized under, and the resulting major themes that emerged from the data analysis (Boyatzis, 1998). Two researchers independently identified key codes, categories, and major themes in a subset of interviews, which were then applied to all the transcripts. The codes were revised and aggregated into subthemes and major themes through an iterative process of analysis and discussion between the lead analyst (R.H.) and the co-authors.

Below, we outlined the major themes that were identified from the interviews. Quotes have been selected to illustrate a concept within the different themes. The source of the quote is indicated in parentheses for conventional farmers $(\mathbf{C})$ or for cow-calf contact farm- ers (CCC), and the number indicates the respondent (i.e., farm number) within the C or CCC groups. Some quotes have been modified to add clarity, indicated by the text in brackets. Efforts have been taken to protect the identity of participants, including removal of details about farming systems that may serve as identifiers, and only presenting quotes from farmers that are not traceable.

\section{RESULTS AND DISCUSSION}

The demographic data of conventional farmer participants are presented in Table 1. Most participants were between 30 and $60 \mathrm{yr}$ of age, with more males than females interviewed. Participants were evenly distributed between the North and South Islands of New Zealand, and they held a range of education levels and roles on the farm. The majority of participants had farm sizes between 100 to 500 cows, which reflected the national herd size distribution and average of 440 cows (LIC and DairyNZ, 2020). Three key themes were identified by conventional farmers as reasons influencing decision-making around provision of cow-calf contact, including animal welfare, labor and staff-wellbeing, and changes to current farm system. These themes and their subthemes are discussed below, and a summary diagram presenting the proportional importance of each theme is highlighted in Figure 1. We then provide an overview of the systems described by the 4 cow-calf contact farmers and their perspectives, organized according to the same themes identified by conventional farmers. Finally, we end with some areas of agreement between conventional and cow-calf contact farmers.

\section{Theme 1: Concerns Around Animal Welfare}

Poorer animal welfare was a substantial concern of the conventional farmers, with around half $(\mathrm{n}=32)$ indicating they felt they were doing what was best for cows by separating the cow and calf; they lacked confidence that cows would care for their calves well, particularly in the early period after birth, so early separation offered more certainty that calves' needs were being met. One farmer said,

"I think it is both beneficial for both mother and calf for us to intervene as much as possible, and just carry out best practice and make sure everybody is happy, healthy and content and their needs met" (C-55).

Comments pertaining to animal welfare and health from conventional farmers centered around the topics 
of colostrum and shelter for calves, bonding and stress of separation, and mastitis in cows.

Colostrum. Over three-quarters of the conventional farmers interviewed $(\mathrm{n}=51)$ emphasized the importance of sufficient and timely colostrum delivery to the calf; most expressed concern that cow-calf contact systems would not promote this outcome:

"The reason I don't do it [keep cows and calves together] is the failure rate of calves not feeding off their mothers. And the importance of them getting the colostrum within the first few hours" (C-53).

Reasons given for perceived poor colostrum intake in cow-calf contact systems included lack of mothering ability of dams (especially heifers) and associated risks of mis-mothering (e.g., large udders and low teats reducing suckling potential), and wet or cold weather making calves less able or inclined to drink.

Minimizing the time to when a calf first receives colostrum is critical to ensuring passive transfer of im-

Table 1. Demographics of interviewed participants $(\mathrm{n}=67)$

\begin{tabular}{|c|c|}
\hline Demographic & $\%$ of participants \\
\hline \multicolumn{2}{|l|}{ Age (yr) } \\
\hline $20-29$ & 1 \\
\hline $30-39$ & 24 \\
\hline $40-49$ & 30 \\
\hline $50-59$ & 24 \\
\hline $60-69$ & 12 \\
\hline$>70$ & 4 \\
\hline \multicolumn{2}{|l|}{ Farm size (no. of cows) } \\
\hline$\leq 100$ & 3 \\
\hline$\overline{100}-299$ & 21 \\
\hline $300-499$ & 31 \\
\hline $500-699$ & 16 \\
\hline$\geq 700$ & 28 \\
\hline \multicolumn{2}{|l|}{ Role on farm } \\
\hline Contract milker & 18 \\
\hline Share owner/share milker & 42 \\
\hline Owner & 28 \\
\hline Farm manager & 12 \\
\hline \multicolumn{2}{|l|}{ Sex } \\
\hline Female & 34 \\
\hline Male & 66 \\
\hline \multicolumn{2}{|l|}{ Region of New Zealand } \\
\hline Northland, Auckland & 10 \\
\hline Waikato & 13 \\
\hline Bay of Plenty, Hawkes Bay & 4 \\
\hline Taranaki & 9 \\
\hline Lower North Island & 15 \\
\hline Canterbury & 15 \\
\hline Southland & 25 \\
\hline Other South Island & 6 \\
\hline \multicolumn{2}{|l|}{ Highest level of education } \\
\hline Some high school & 6 \\
\hline High school & 28 \\
\hline Trade training & 25 \\
\hline University & 33 \\
\hline Not specified & 3 \\
\hline
\end{tabular}

Journal of Dairy Science Vol. 105 No. 1, 2022 munity, and is a key recommendation for good colostrum management (Godden et al., 2019). Several studies recommended colostrum feeding should be within $2 \mathrm{~h}$ after birth as the likelihood of failure of passive transfer increases and IgG absorption declines after this (Chigerwe et al., 2008; Fischer et al., 2018; Shivley et al., 2018); thus, both conventional and cow-calf contact systems are at risk of failing to feed colostrum in a timely manner. For instance, colostrum delivery is delayed when farmers move calves into the calf shed only once per day (Cuttance et al., 2017a), a common practice on New Zealand dairy farms. There is conflicting evidence as to whether hand-feeding colostrum versus allowing the calf to suckle is more effective at achieving passive transfer of immunity (Beaver et al., 2019; Johnsen et al., 2019); thus, regardless of system, we suggested some degree of farmer intervention or oversight is recommended as part of good colostrum management.

Shelter. Three-quarters of conventional farmers (n $=48$ ) mentioned the importance of calves having warm and dry shelter. The calf shed was viewed as the best place after birth for prevention of sickness and exposure, and the lack of such shelter was identified by some as a downside of cow-calf contact systems as follows:

"If the cows and calves are together and you get bad weather, there is no shelter for them. When we take them off, at least they are under a roof and are getting fed twice a day" (C-16).

A cold and wet climate during the calving season is a known risk factor for increased newborn calf mortality (Cuttance et al., 2017b). For pastoral cow-calf contact systems to be viable, calf shelter concerns must be addressed; this is particularly pertinent on average to large sized farms, where 10 to 30 calves may be born in a day. For example, provision of small shelters in paddocks for calves to use may be an option. However, proper ventilation in shelters should be considered as this is a key factor affecting morbidity rate in indoorhoused calves (Urie et al., 2018).

Bonding and Stress of Separation. The majority of conventional farmers $(\mathrm{n}=49)$ felt that keeping calves on cows would create more problems, particularly stress for the cows (e.g., at milking times and later at complete separation). For example, one participant stated, "Once they get that bond, it is hard to keep the cows in [the paddock], I think the cow is under stress for longer, and she bellows all day and night" (C-15). Additionally, one farmer, reflecting on a "partial cowcalf contact system" (e.g. where calves are kept with the cows overnight or a portion of the day) they had seen in the past, felt this was more stressful for the 


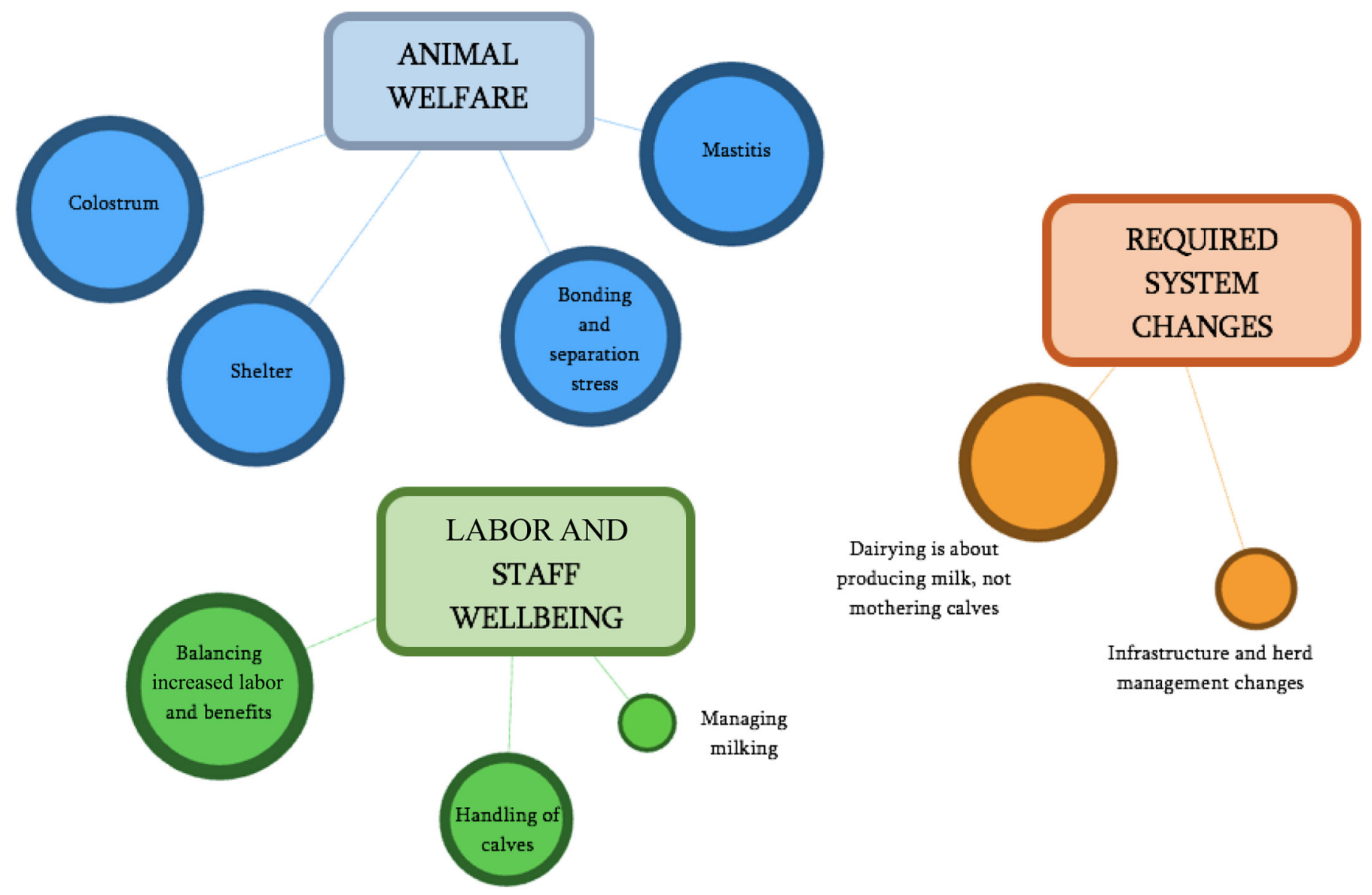

Figure 1. Themes and subthemes representing key barriers regarding provision of cow-calf contact for 63 conventional New Zealand dairy farmers who separated cow and calf within $48 \mathrm{~h}$ after birth. Square boxes represent major themes, and circles represent subthemes, where the size of the circle is proportional to the number of farmers raising this subtheme. Dairy farmers who provided cow-calf contact for more than 48 $\mathrm{h}(\mathrm{n}=4)$ were also interviewed but are not included in this figure.

cows than no contact at all and stated, "It was a lot of hassle and a lot more stress on the cows I reckon. They were with their calves and they were away from them, and they were with them [again]" (C-13).

Just over one-third of conventional farmers $(\mathrm{n}=24)$ commented that they felt cows were affected by the separation process, but over two-thirds of these farmers expressed doubt about its importance or how long it lasted as follows:

"I think they do miss them for that brief period when they are separated and some cows that are really motherly and do miss them for a day, but when you open up a paddock of grass and the mother has her calf with her, she will choose the food every single time" (C-9).

Another farmer believed that the cows are used to the system and stated, “... I don't think it matters [to the cow if her calf is removed]. Only because it has been done for so many years" (C-43). On the other hand, several farmers $(n=7)$ indicated that their management choices were done with consideration for cows' feelings, and their actions were motivated in part by wanting to minimize the effect on the animal, with some citing personal experience, such as the following example:

"Just from a personal [perspective], being a mum, it would seem like they had that much more bonding time [if they were left together for longer] to just get ripped away from each other" (C-33).

Research suggests that the acute responses of cows and calves to separation (vocalizations, time spent moving, and time with head out of pen) are more intense and prolonged when separation is delayed (4-14 d after birth), particularly when visual and auditory contact is maintained (Lidfors, 1996; Weary and Chua, 2000; 
Flower and Weary, 2001). Calves also show a negative emotional response in the form of a pessimistic judgment bias after separation from the cow (Daros et al., 2014), but no work has examined if cows also show this bias. Nonetheless, these studies suggest that these behavioral and emotional stress responses to separation should be minimized if cow-calf contact systems are to be considered; work in indoor-housed dairy cattle supports a 2-stage process of separation, where calves are first prevented from suckling, followed later by physical separation (Johnsen et al., 2016). It is currently unknown if cows and calves experience positive emotional benefits from extended cow-calf contact; therefore, it remains difficult to determine if the emotional stress in eventual separation is worth the possible benefits of cow-calf contact. However recent work has demonstrated suckling cows are motivated to reunite with their calf more so than nonsuckling or separated cows (Wenker et al., 2019), which suggests there is a bond between cow and calf.

Mastitis. A specific area of concern from many conventional farmers $(n=50)$ was the increased chance of mastitis and damage to cow udder health in cow-calf contact systems (e.g., if calves do not drink enough or at all, or if they fail to drink from all the teats). A further concern was that treatment of mastitis could be delayed. As one conventional farmer said, "If the cows got a crook [bad] quarter it is not going to get treated until she comes in. The longer it is left with the calf on it, it could be manifesting itself" (C-1). Additionally, 3 farmers commented on the possibility of calves causing teat damage if left with their mothers.

An increased likelihood of teat damage in suckling cows, particularly those that nursed several calves, was reported by Thomas et al., (1981), but a recent review of 18 studies examining mastitis in cow-calf contact systems found that suckling cows were less likely to develop mastitis than nonsuckling cows (Beaver et al., 2019). However, most of these studies were conducted in indoor-housed dairy cattle, so there may be differences in mastitis or other udder health issues for pasturebased suckling cows that have yet to be determined.

Overall, these concerns from conventional farmers around colostrum and shelter for calves, and mastitis in cows, suggested an underlying attitude that animal health may be at risk in cow-calf contact systems. Currently there is little evidence supporting the belief that immediate separation of the cow and calf is best for animal health (reviewed by Beaver et al., 2019). However comparative research is still very limited and is almost exclusively conducted in indoor-housed dairy cattle, so findings may be different in pasture-based dairy systems.

\section{Theme 2: Concern for Labor and Staff Well-Being}

A second theme that emerged from the interviews with conventional farmers was related to labor requirements for cow-calf contact systems and the well-being of staff.

Balancing Increased Labor and Benefits. Over three-quarters of conventional farmers $(\mathrm{n}=51)$ felt that cow-calf contact systems would require considerably more labor and effort or would make farm management more complicated. On farmer stated, "If it is going to take twice as long as what you are already doing, then there has got to be some pretty decent benefits" (C44). About one-third of conventional farmers $(\mathrm{n}=21)$ mentioned that the extra effort required for cow-calf contact systems would compromise staff well-being, leading to greater stress and hassle, or have negative implications for safety. Another farmer expressed a tension between doing what is best for cows and ensuring the health of farmers and workers and said, "We are all on time restrictions and I think often what could be better for the animal could be quite detrimental to the farmer by way of mental health and added pressure" (C-33).

Managing Milking. About one-quarter of conventional farmers $(\mathrm{n}=16)$ felt milking, and bringing cows to the milking parlor, would be difficult and stressful for staff in a cow-calf contact system. This sentiment was expressed as follows:

"...calves are not well behaved either... they can disappear, and the cows will follow and break things... The mob [herd] won't go to milking because one calf is running around" (C-8).

Handling of Calves. About a quarter of conventional farmers $(\mathrm{n}=15)$ also highlighted challenges with handling cow-reared replacement heifers. One farmer described his father's experience with raising replacements on nurse cows; although they performed well, they "were very hard to handle and dangerous" (C-7). Others commented on cow-raised calves being more independent, wild, or "spooky" (C-63), whereas farmer-reared calves were more trusting of people. A few farmers emphasized the health and safety risks associated with a cow-calf contact approach. One participant stated, "Under health and safety you couldn't do it [keep cows and calves together]. I would knowingly put my staff in harm... [if I did that]. Cows get more protective. You couldn't do it with a clear conscience" (C-7).

Later separation (e.g., keeping cows with calves beyond $24 \mathrm{~h}$ ) tended to be viewed negatively by conven- 
tional farmers $(\mathrm{n}=30)$, who noted that it was harder to pick up older calves, as they are "easier to lift when they are lighter" (C-14), and they "get a bit sprightly" $(\mathrm{C}-43)$ and harder to catch after $24 \mathrm{~h}$. Some $(\mathrm{n}=6)$ felt that a longer time together made it harder to teach calves to feed after separation from the cow.

Cow-calf contact systems may involve a re-distribution of labor, where the time saved on calf rearing is re-invested in other tasks. European farmers interviewed by Vaarst et al. (2020) described how cow-calf contact systems required them to re-think time and efforts invested in their animals, with time freed up from calf rearing still needing to be spent with and around the calves. This redirection of labor also provided opportunities to familiarize calves with humans. Little empirical work has investigated the labor costs associated with conventional rearing versus cow-calf contact systems. A Norwegian study estimated that cow-calf contact systems reduced labor cost by $5 \mathrm{~h} /$ calf for a 7-wk milk-feeding period compared with a conventional rearing system, and no change in time spent per cow was anticipated (Asheim et al., 2016). A similar economic analysis is necessary for pasture-based and seasonal-calving systems, ensuring that a variety of calf-rearing practices for both conventional rearing and cow-calf contact systems are assessed. A framework for such an approach has been proposed (Knierim et al., 2020).

\section{Theme 3: Concern for Required System Changes}

A third theme that was identified centered around the overall dairy farm system itself, where almost all conventional farmers expressed some concerns that the system change required to run extended cow-calf contact systems would be undesirable or nonviable. This sentiment was often in the form of a desire to "keep things the same." This desire was expressed by the majority of farmers $(n=47)$ for a range of reasons; for some, it was the normal way of operation with which they were familiar and confident. Other farmers expressing this idea felt their current system worked well, were uninterested in changing, or explicitly liked parts of it (e.g., enjoyed the calf-rearing process). An example of this sentiment is as follows:

"[If I didn't have any constraints] I would like the calf sheds because it is quite a neat activity feeding calves and rearing them. I wouldn't get close to the animals if I didn't have that job feeding calves. I would do it the way we do it" (C-14).

A few conventional farmers saw that their current system was a result of learning and adjustments over time, with earlier separation or less contact with cows being an improvement on past practices. For such farmers, a movement back to having longer contact times was viewed critically. One participant stated, "We have probably been doing this system [separate soon after birth] for 10 to 15 years. Beforehand... we left them on the cows longer and didn't check them as often. We just upped the game learning from mistakes, really it is hard to go back now learning from what we have done" (C-5).

Infrastructure and Herd Management Changes. Conventional farmers $(\mathrm{n}=22)$ felt that cow-calf contact systems would require significant change, particularly around infrastructure and herd sizes. This was described as including more fencing, creating smaller and calf-proof paddocks for the new cows and calves each day, as well as more housing for calving and calves. A possible shelter alternative was suggested to include calving under trees; one Southland farmer, although not open to contact systems, saw that calving in a spaced pine plantation kept them sheltered and helped avoid calf losses. Several farmers $(n=7)$ commented that contact systems would create larger herds of cows to manage on the farm, as there would be calves as well as cows in each herd.

One farmer in particular noted that a contact system would require substantial system change and rethinking of farm goals. He saw that it would have implications for his whole system, rather than only the calf-rearing process being affected and stated the following:

"I would have to change the yard management, grazing management, insemination times, bull management, and also the surviving of calves will be a little bit less. A lot of calves will die because they will never get any drinks from any cow" (C41).

Some farmers $(\mathrm{n}=9)$ described the importance of being financially viable, or how costs associated with a new system, such as infrastructure or labor, would be prohibitive even if they were keen to provide cow-calf contact. An example is as follows:

"I haven't seen any model that works well and the farms I have known that have tried to do it seem to frequently go bankrupt... You would have to more than double the labor I would need to see a double milk price then" (C-21).

Regardless of the calf-rearing system, there was a strong emphasis on the need to adapt calving management and calf rearing to specific environments and situations. For instance, the following quote represents this idea: 
"It is more area-specific the ways you can do things. What we can do on the west coast [is different from what farmers in other areas can do]... It can even be farm-specific, not always area-specific" (C-25).

These comments demonstrated that farmers' views on provision of cow-calf contact were positioned within the larger context of dairy farming, which echo comments from interviewed North American participants with some level of dairy industry involvement (Ventura et al., 2013). Pasture-based and seasonal-calving dairy systems such as those of New Zealand face different challenges to those of indoor-housed dairy farms; seasonal pastoral calving results in a large number of calves born outdoors in a matter of days, and rotational grazing would require improved paddock fencing for calves. Herd management of cows and calves and the milking process were noted as being possible for herds around 50 cows, but seen as problematic for typically large New Zealand farms managed exclusively outdoors (farm size average of 440 cows, with $16 \%$ of farms having over 700 cows; LIC and DairyNZ, 2020). Therefore, it is necessary to investigate how cow-calf contact systems may be implemented on large pasture-based commercial farms without compromising the welfare of animals and staff.

Dairy Farming Is About Producing Milk, Not Mothering Calves. Many conventional farmers ( $\mathrm{n}=$ 43) felt that cows have been bred for milk production, and thus cow-calf contact systems would not be suitable. Cows were described as "milking machines.... not designed to have a calf on them" (C-59), with udder shape leading to some difficulties as follows:

"... I find with high producing cows, they get very large udders and the calf cannot [or] doesn't feed off them because the udder is too big and the teats are too low. So the thought of leaving them on because they are getting colostrum is very misleading" (C-53).

Some conventional farmers $(\mathrm{n}=8)$ highlighted a potential decrease in milk production as a significant downside of cow-calf contact systems. As one farmer said, "We are about producing milk. That is why we wouldn't leave them on for longer" (C-17).

A few studies have shown reduced milk yield from cows that suckled calves (e.g., lower yield during and after calf separation; Barth, 2020), whereas a systematic review found no consistent evidence of a negative effect of cow-calf contact on milk production during the suckling period or in the long term (Meagher et al., 2019). The authors of this review suggested a case of lower milk yield is likely due to consumption by suckling calves; therefore, it should not be considered a loss, but rather a redirection of direct costs (i.e., milk powder) to indirect costs (i.e., temporary loss of saleable milk).

In addition, about two-thirds of conventional farmers ( $\mathrm{n}=39)$ commented that modern dairy breeds would not be suitable mothers for rearing calves. Some approached this topic indirectly, describing how mothering ability was variable in their cows. "Some cows are brilliant mothers and there are some cows that are terrible mothers" (C-17). Similarly, some talked about the chances of mis-mothering increasing if cows and calves were left together for longer, implying that their cows could not be relied upon to consistently care well for their calves. Some explicitly commented that these mothering qualities had been bred out of dairy cows over time as follows:

"I'm not saying that it has been done deliberately, but if you look at the mothering ability of cows today compared to the cows that were bred 30 years ago, you would find the mothering ability has been quietly eroded" (C-27).

Some research has shown that modern dairy breeds express maternal behaviors toward the newborn calf, including sniffing, licking, and nursing of the calf, especially in the first hours after birth (Jensen, 2011, 2012). However, there is natural individual variation in mothering quality (Edwards and Broom, 1982) and how frequently the cow chooses to visit the calf through an access gate for suckling and allogrooming (Johnsen et al., 2021). It is also possible that some cows may reject their own calf; one study of heifers calving in groups observed 1 of $31(13 \%)$ heifers rejected its calf within $6 \mathrm{~h}$ after birth (Illmann and Špinka, 1993). The notion of leaving calf rearing to the cow can be uncomfortable for farmers, given that calf rearing by the farmer offers a sense of control over the process (Vaarst et al., 2020); thus, adopting a cow-calf contact system would involve an attitudinal shift in trust that the cow is capable to rear her calf, and relinquishing some control over the process by replacing hands-on care with observation of the animals in the paddock.

\section{Cow-Calf Contact Systems and Perspectives of Cow-Calf Contact Farmers}

Only a small number of farmers in New Zealand provided a system of extended cow-calf contact (to our knowledge, fewer than 10 farmers), of which 4 responded to be interviewed for this study. This small sample size may not represent all farmers who provide cow-calf contact in New Zealand, but their perspectives on this 
topic serve as a starting point for discussion of possible cow-calf contact systems in pasture-based dairy farming. The herd sizes of farms providing cow-calf contact were 14 to 140 cows, much smaller than those of the conventional farmers.

Cow-Calf Contact System Descriptions. All 4 cow-calf contact farmers allowed contact between cow and calf for at least $4 \mathrm{wk}$ after birth, and 3 of the 4 farmers reared both male and female calves. Each of these farmers had different approaches to providing cow-calf contact. Two of the approaches involved keeping cows on calves and milking cows in a milking shed, one involved the use of mobile milking machines, and another kept replacement heifer calves on nurse or foster cows (2 calves to a cow) and milked the rest of the herd conventionally. In one system, the calves were taken off mothers overnight after 4 to 6 wk of age to reduce effects on loss of saleable milk, and then they were weaned at 3 to 5 mo. Another system kept calves on their mothers and weaned calves at $10 \mathrm{wk}$. In the nurse or foster cow system, calves were fed from a colostrum mob and then replacement heifers continued to be raised on nurse or foster cows ( 2 calves to a cow) until weaning. These different methods of providing cow-calf contact suggest that there may be flexibility in how these systems can be operated in pasture-based systems. Some of these approaches to providing extended cow-calf contact were also described by European farmers with indoor-housing systems, including nurse or foster cow systems, and calves reared by their mothers and subsequently abruptly or gradually separated at weaning (Vaarst et al., 2020).

Most of the conventional farmers had not considered providing cow-calf contact for the majority of their calves, but a small number $(\mathrm{n}=11)$ reported some experience with cow-calf contact systems. These experiences included use of nurse or foster cows ( $\mathrm{n}=$ 4 ), keeping calves that were born early or late in the season on their mothers for a period (sometimes up to 2-3 wk), often to avoid milking small numbers of cows $(\mathrm{n}=6)$, or raising buffalo calves on their mothers ( $\mathrm{n}$ $=1$ ). Another 23 conventional farmers mentioned that they had heard of people providing cow-calf contact, had read articles about it, or had seen others practicing cow-calf contact. One farmer described how he had considered using mobile milking machines to milk his cows and just had not gotten around to preparing the infrastructure to be able to do this. Although the public typically expresses support for cow-calf contact (see review by Placzek et al., 2021), there is currently no work examining the specific type of cow-calf contact system that would be viewed as acceptable by the public; for instance, a nurse or foster cow operation still involves most cows and calves being separated from their biological offspring and mothers.

Perspectives of Cow-Calf Contact Farmers. Cow-calf contact farmers that previously reared calves conventionally were motivated by a range of reasons, including benefits to the animals, ease of the system, public perception and consumer demand, and personal reasons such as ethical beliefs. Similar to the rationale of some conventional farmers, one farmer used a cowcalf contact system because that is what their current farm infrastructure supported (i.e., continued to use a nurse or foster cow system adopted by their parents). The cow-calf contact farmers also made comments indicating animal welfare and health were important to them; however, they indicated that contact systems promoted, or at least did not create insurmountable obstacles, to achieving good welfare. Indeed, it was cited as a primary motivator for changing to a cow-calf contact system by at least one cow-calf contact farmer as follows:

"We literally get zero calf sickness. Because the cows aren't stressed out by having their calves taken away, they get over the birth much quicker. We don't have any problems with metritis because they just kick out the afterbirth [and] are being milked all the time" (CCC-1).

Cow-calf contact farmers were not concerned about colostrum; 2 farmers felt that calves grew better when reared on cows (either dam or nurse or foster cow); one stated, "...I want it to get the best opportunity for growth and animal health so keeping them on their mum is the best thing to do" (CCC-4). This exemplified that some cow-calf contact farmers associated cow-calf contact systems with improved calf growth and health. A need for shelter or protection for the calves was mentioned by 2 cow-calf contact farmers; one located in the South Island (e.g., cold and wet calving season) noted a need to ensure calves did not become too cold, either by putting covers on the calves or by avoiding winter or spring calving. Another chose to put calving cows into a sheltered paddock with trees. Mastitis was not mentioned as an area of concern for cow-calf contact farmers, with one farmer explaining this is because their cows were being "milked all the time" (CCC-1) rather than having extended periods without milking.

Three of the 4 cow-calf contact farmers felt that their system provided "an easy system" (CCC-3) and saved labor because "you don't have any extra staff members to feed [calves]" (CCC-3). Another farmer described it as, "I didn't have to separate calves and I didn't have to feed calves. I didn't have to have separate mobs. It is 
just a pretty 'hands off' system" (CCC-2). However, the farmer who permitted the calves to come to the parlor for milking did comment that it took cows a couple of weeks to settle into this milking routine. There was also concern from one cow-calf contact farmer (who planned to adopt the system) that milking management was "... going to be a pain [annoying] for the guys" (CCC-4). In contrast to concerns from conventional farmers, cowcalf contact farmers commented that cow-reared heifers were "still... quite friendly, and they don't go wild or anything like that" (CCC-3), or that they became more friendly after weaning. However, this effect could have also been related to greater opportunity for human contact when farms were small in size. Some evidence suggests larger farm sizes lead to a higher number of fearful calves (Leruste et al., 2012), but other factors such as calf manager behavior and attitude are likely to be most important (Calderón-Amor et al., 2020).

Cow-calf contact farmers recognized that adjustments to infrastructure were needed for a cow-calf contact system, with fencing being a necessity. One farmer said, "You could set this model up with a big farm, you just have the infrastructure to change. A lot of fencing" (CCC-1). Another cow-calf contact farmer that used mobile milking machines felt that it could be challenging to bring cows and calves into the milking parlor, but a farmer about to commence this system felt that they would be able to set up rails to help manage calves during milking.

Some cow-calf contact farmers mentioned possible saleable milk losses, but it was noted that "we gain so much back in cow and calf health and we obviously don't pay a calf rearer, so it just saves time and money back again" (CCC-1). This farmer felt that the milk losses and health benefits would "even out," and this was echoed by another cow-calf contact farmer who noted benefits for calf nutrition, as well as reduced labor requirements.

One cow-calf contact farmer directly opposed the perspective that dairy cows were not good mothers and said, "The cows are such good mothers. People who say dairy cows are bad mothers, it just such a lie" (CCC-1). Another cow-calf contact farmer stated that they had only encountered "one or two cows that didn't want to take their calves" (CCC-2). The farmer running a nurse or foster cow system noted that some cows took a bit longer to be willing to accept foster calves, but were fine once they settled in.

Summary of Insights from Cow-Calf Contact Farmers. Although only a few cow-calf contact farmers were able to be contacted out of 10 known to the research team, their perspectives regarding managing cows and calves together provided useful insight into how this system could be managed in a pasture-based system, at least on a small scale. Some of the concerns raised by conventional farmers about colostrum and mastitis, or increased labor, were not reflected in the commentary from cow-calf contact farmers. Currently there is little empirical evidence to support either system on the issues of colostrum (passive transfer of immunity) or mastitis (Beaver et al., 2019), and no studies have examined the labor input required for either rearing option in a pasture-based system. Cow-calf contact farmers offered a few approaches to address the issue of shelter, including putting covers on calves, calving under trees, or shifting the timing of calving. The latter 2 approaches would require more system-level changes, as not all farmers have trees available in their paddocks, and the standard late winter-early spring calving season is desirable for spring grass growth and sale of milk. Cow-calf contact farmers also emphasized additional infrastructure and fencing required, which is likely to become costly with increasing farm size. Currently, it remains to be seen how extended management of cows and calves together can be done practically and economically on larger commercial seasonal-calving pastured-based dairy farms.

\section{Areas of Agreement Among Conventional and Cow-Calf Contact Farmers}

Benefits in Providing Some Cow-Calf Contact. About one-quarter of conventional farmers $(\mathrm{n}=$ 19) indicated that they felt there were some benefits in cows and calves having some time together after birth, rather than being separated immediately after birth. This particularly centered around the benefits of calves getting their first feed of colostrum from their mother $(\mathrm{n}=12)$. One participant stated, "They learn to suckle quick, they get that colostrum straight off the mum, you know they have got it. The immunity is a lot better I feel. They are just more alive and sprightly" (C-43). Another farmer described it the following way:

"We leave the calves on for a good day and night out in the paddock for the colostrum. Colostrum is \#1.... On this farm, calves spend a good 24 to 48 hours on the cow. I know farmers that rush out there and snatch the thing straight away. They get bugs and problems" (C-19).

A few farmers $(\mathrm{n}=6)$ also saw some benefits for the cow, such as being allowed to clean the calf, and the calf's presence helping the cow with milk let-down and recovery from calving. It was observed that this time together could help "the cow's peace of mind" (C-50), as well as help sick calves or cows recover from calving, without the added stress of separation at birth. Al- 
though the majority of conventional farmers expressed concern that calves would not receive sufficient colostrum if left with their mothers, the comments in this section indicated that some conventional farmers had a different perspective.

Dissonance. The majority of conventional farmers were strongly in support of current practices, but about one-quarter $(\mathrm{n}=17)$ made comments that highlighted some cognitive dissonance (i.e., a disconnect between beliefs or values and what is actually practiced; Festinger, 1957). Most of these farmers were interested in, or theoretically preferred, cow-calf contact systems; they saw drawbacks to conventional systems, but for various reasons, felt that they needed to continue with a conventional system. Some of these farmers felt that they would provide cow-calf contact if it was "a perfect world" (C-7, C-18), but contact systems were not viewed as being practical or realistic; these farmers mentioned lacking facilities, needing to make money, wanting calves to be better cared for, or cow-calf contact creating problems. One farmer, referring specifically to animal welfare stated the following:

"Ideally yes, I would like to see the cow and the calf bonded for three days, but it just doesn't work and the numbers you are talking about from an animal welfare point of view... they are better taken off and [put] into shelter" (C-53).

A subset of these farmers $(n=6)$ were also quite aware of the feelings of their stock, and thus felt a sense of discomfort when they had to separate the cow and calf. However, they also felt that this separation was necessary and unavoidable. "It [separating cows and calves] is a stressful time for everyone I think. Cow, calf, and the person separating them. It is just what you have to do" (C-61).

This dissonance demonstrated that these farmers had concerns for the cow and calf, but saw multiple constraints preventing them from using cow-calf contact systems. Nonetheless, the existence of this disconnect in beliefs and actions suggested that there is some willingness to explore the possibility of providing cow-calf contact.

Incentives to Use Cow-Calf Contact Systems. When asked specifically about incentives, many farmers were not open to incentives to change to cow-calf contact systems ( $\mathrm{n}=30$ of 51 farmers asked about incentives). The remainder $(\mathrm{n}=21)$ of these farmers were hesitant, but indicated they might be open to some incentives. Only some mentioned specific incentives, as follows: (1) financial incentives $(\mathrm{n}=2),(2)$ having the right farm set up for it, including needed infrastructure $(\mathrm{n}=2)$, and (3) having information on contact systems from research trials or farmers who have used them $(\mathrm{n}=4)$. One farmer expressed hesitancy about trying cow-calf contact systems without clear research on the topic. Public perception of calf rearing was mentioned by several farmers from both conventional and cow-calf contact groups $(\mathrm{n}=9)$. One of the cow-calf contact farmers felt that public perception should be a motivating factor for farmers to consider contact systems, but the conventional farmers who mentioned public perception were less positive about it. They saw public attitudes or aspirations for calf rearing as idealistic or unrealistic. One farmer said, "I think the general public would love for calves to be kept on cows... in reality it is a nice dream, but the reality of it is it doesn't work and it will lead to further problems down the track" (C-55). These statements indicated that although some farmers are aware of public perception of calf-rearing systems, neither negative or positive public views are currently providing motivation for most farmers to consider system change.

Although financial incentives can be powerful motivators for behavior change on farms (Whay and Main, 2010), they are unlikely to be successful if the change required does not align with the farmer's values. For instance, a primary motivating factor for Swedish dairy farmers in their work was "to feel happy knowing that [their] dairy cows are well-kept," suggesting that some farmers' values around animal welfare are not just about profitability and productivity (Hansson and Lagerkvist, 2016). However, Brazilian pig farmers indicated that economic reasons were a main driver of their decisions to not provide environmental enrichment to their pigs (Borges et al., 2019). These studies demonstrate that farmers' adoption of different practices on farm can stem from inner motivation (i.e., their own values regarding the system, such as feeling the animals have improved welfare) or external factors (e.g., current circumstances, financial reasons, public perception).

\section{General Discussion}

Our study offered a description of the perspectives of New Zealand dairy farmers regarding providing extended cow-calf contact in a pasture-based dairy system, which may be informative for other farms with similar characteristics such as seasonal calving, seasonal grazing, or large herd sizes. The predominant concerns around animal welfare of the cow and calf, labor, and the suitability of the dairy system for providing extended cow-calf contact are similar to those expressed by smallholder dairy farmers in Brazil as reasons for supporting separation of cows and calves soon after birth (Hötzel et al., 2014). Dairy professionals in North America also cited animal welfare reasons 
as being the primary rationale for separation, and questioned the changeability of the dairy system to accommodate cow-calf contact (Ventura et al., 2013). Some of the specific concerns raised by conventional farmers (such as separation stress, wild or difficult calves, and lower milk production) were also reflected in commentary from European farmers that expressed interest in cow-calf contact systems (Vaarst et al., 2020). Overall, comments from conventional farmers indicated that many would be reluctant to alter their farming system to accommodate extended cow-calf contact, owing to practical and economic barriers. Many of the practical and economic reasons for removing calves from cows could be attributed to the large herd sizes and the pasture-based, seasonal-calving dairy system of New Zealand; in particular, the management of a large number of calves born in a short time frame and reared outdoors (with a risk of inclement weather), and the management of cows and calves together around milking were identified as key challenges. Comparative health outcomes of calves and cows, namely colostrum intake and mastitis, were important considerations in both cow-calf contact and conventional pasture-based systems. Most of the conventional farmers only had experience with early-separation systems, making it difficult to determine whether their attitudes toward providing cow-calf contact stemmed from theoretical knowledge about early separation (e.g., early career experiences, social norms around how milk is harvested from cows) versus their direct experiences with the system. It would be valuable to conduct more in-depth interviews with the farmers who reported experiences with both early separation and cow-calf contact systems. Some of the conventional farmers in our study indicated they saw some benefits of initial cow-calf contact. A potential way of building on these perceived benefits of initial cow-calf contact may involve farmer peer support group; these have previously worked well in providing social and experiential support for farmers shifting their systems (Vaarst et al., 2007; Roche et al., 2015) and can successfully motivate behavior change (Sumner et al., 2018) if dairy calves are required to be managed together with cows in the future.

\section{CONCLUSIONS}

Overall, our study of conventional and cow-calf contact dairy farmers revealed diverse views on the practice of providing extended cow-calf contact in New Zealand, especially around animal welfare, labor, and systemlevel practices. However, there was common ground in concerns about animal welfare from both groups of farmers. This mutual area of interest could be an area of future work.

\section{ACKNOWLEDGMENTS}

The authors thank Penny Payne (People and Agriculture, AgResearch, New Zealand) for helpful comments on earlier drafts of this report and Margaret Brown (People and Agriculture, AgResearch, New Zealand) for comments on survey design. We greatly appreciate the help of Cindy Svensson (independent contractor, New Zealand) for transcribing the 67 interview audio recordings. Finally, we thank the 67 farmers for dedicating their time to participating in this survey and sharing their valuable perspectives on this topic. This study was funded by the Ministry of Business, Innovation and Employment Strategic Science Investment Fund (SSIF) C10X1702 (Wellington, New Zealand) and the New Zealand dairy farmers through DairyNZ Inc. (Hamilton, New Zealand), contract 2020-1598. The authors have not stated any conflicts of interest.

\section{REFERENCES}

Asheim, L. J., J. F. Johnsen, Ø. Havrevoll, C. M. Mejdell, and A. M. Grøndahl. 2016. The economic effects of suckling and milk feeding to calves in dual purpose dairy and beef farming. Rev. Agric. Food Environ. Stud. 97:225-236. https://doi.org/10.1007/s41130 -016-0023-4.

Barth, K. 2020. Effects of suckling on milk yield and milk composition of dairy cows in cow-calf contact systems. J. Dairy Res. 87(S1):133-137. https://doi.org/10.1017/S0022029920000515.

Beaver, A., R. K. Meagher, M. A. G. von Keyserlingk, and D. M. Weary. 2019. Invited review: A systematic review of the effects of early separation on dairy cow and calf health. J. Dairy Sci. 102:5784-5810. https://doi.org/10.3168/jds.2018-15603.

Boogaard, B. K., B. B. Bock, S. J. Oosting, J. S. C. Wiskerke, and A. J. van der Zijpp. 2011. Social acceptance of dairy farming: The ambivalence between the two faces of modernity. J. Agric. Environ. Ethics 24:259-282. https://doi.org/10.1007/s10806-010 $-9256-4$.

Borges, J. A. R., C. H. F. Domingues, F. R. Caldara, N. P. Rosa, I. Senger, and D. G. F. Guidolin. 2019. Identifying the factors impacting on farmers' intention to adopt animal friendly practices. Prev. Vet. Med. 170:104718. https://doi.org/10.1016/j.prevetmed .2019.104718.

Boyatzis, R. E. 1998. Transforming Qualitative Information: Thematic Analysis and Code Development. SAGE Publications Inc.

Busch, G., D. M. Weary, A. Spiller, and M. A. G. von Keyserlingk. 2017. American and German attitudes towards cow-calf separation on dairy farms. PLoS One 12:e0174013. https://doi.org/10.1371/ journal.pone.0174013.

Calderón-Amor, J., A. Beaver, M. A. G. von Keyserlingk, and C. Gallo. 2020. Calf- and herd-level factors associated with dairy calf reactivity. J. Dairy Sci. 103:4606-4617. https://doi.org/10.3168/ jds.2019-16878.

Cardoso, C. S., M. A. G. Von Keyserlingk, and M. J. Hötzel. 2017. Brazilian citizens: Expectations regarding dairy cattle welfare and awareness of contentious practices. Animals (Basel) 7:89. https:// doi.org/10.3390/ani7120089.

Chigerwe, M., J. W. Tyler, L. G. Schultz, J. R. Middleton, B. J. Steevens, and J. N. Spain. 2008. Effect of colostrum administration by use of oroesophageal intubation on serum IgG concentrations in Holstein bull calves. Am. J. Vet. Res. 69:1158-1163. https: //doi.org/10.2460/ajvr.69.9.1158.

Clark, B., G. B. Stewart, L. A. Panzone, I. Kyriazakis, and L. J. Frewer. 2016. A systematic review of public attitudes, perceptions and behaviours towards production diseases associated with farm 
animal welfare. J. Agric. Environ. Ethics 29:455-478. https://doi .org/10.1007/s10806-016-9615-x.

Cuttance, E. L., W. Mason, R. Laven, J. McDermott, and C. Phyn. 2017a. Prevalence and calf-level risk factors for failure of passive transfer in dairy calves in New Zealand. N. Z. Vet. J. 65:297-304. https://doi.org/10.1080/00480169.2017.1361876.

Cuttance, E. L., W. A. Mason, J. McDermott, R. A. Laven, S. McDougall, and C. V. C. Phyn. 2017b. Calf and replacement heifer mortality from birth until weaning in pasture-based dairy herds in New Zealand. J. Dairy Sci. 100:8347-8357. https://doi.org/10 .3168/jds.2017-12793.

Daros, R. R., J. H. C. Costa, M. A. G. von Keyserlingk, M. J. Hötzel, and D. M. Weary. 2014. Separation from the dam causes negative judgement bias in dairy calves. PLoS One 9:e98429. https://doi .org/10.1371/journal.pone.0098429.

Edwards, S. A., and D. M. Broom. 1982. Behavioural interactions of dairy cows with their newborn calves and the effects of parity. Anim. Behav. 30:525-535. https://doi.org/10.1016/S0003 $-3472(82) 80065-1$.

Ellis, K. A., K. Billington, B. McNeil, and D. E. F. McKeegan. 2009. Public opinion on UK milk marketing and dairy cow welfare. Anim. Welf. 18:267-282.

Festinger, L. 1957. A Theory of Cognitive Dissonance. Stanford University Press.

Fischer, A. J., Y. Song, Z. He, D. M. Haines, L. L. Guan, and M. A. Steele. 2018. Effect of delaying colostrum feeding on passive transfer and intestinal bacterial colonization in neonatal male Holstein calves. J. Dairy Sci. 101:3099-3109. https://doi.org/10.3168/jds 2017-13397.

Flower, F. C., and D. M. Weary. 2001. Effects of early separation on the dairy cow and calf: 2 . Separation at 1 day and 2 weeks after birth. Appl. Anim. Behav. Sci. 70:275-284. https://doi.org/10 .1016/S0168-1591(00)00164-7.

Godden, S. M., J. E. Lombard, and A. R. Woolums. 2019. Colostrum management for dairy calves. Vet. Clin. North Am. Food Anim. Pract. 35:535-556. https://doi.org/10.1016/j.cvfa.2019.07.005.

Hansson, H., and C. J. Lagerkvist. 2016. Dairy farmers' use and nonuse values in animal welfare: Determining the empirical content and structure with anchored best-worst scaling. J. Dairy Sci. 99:579-592. https://doi.org/10.3168/jds.2015-9755.

Hötzel, M. J., C. S. Cardoso, A. Roslindo, and M. A. G. von Keyserlingk. 2017. Citizens' views on the practices of zero-grazing and cow-calf separation in the dairy industry: Does providing information increase acceptability? J. Dairy Sci. 100:4150-4160. https:// doi.org/10.3168/jds.2016-11933.

Hötzel, M. J., C. Longo, L. F. Balcão, C. S. Cardoso, and J. H. C. Costa. 2014. A survey of management practices that influence performance and welfare of dairy calves reared in Southern Brazil. PLoS One 9:e114995. https://doi.org/10.1371/journal.pone.0114995.

Illmann, G., and M. Špinka. 1993. Maternal behaviour of dairy heifers and sucking of their newborn calves in group housing. Appl. Anim. Behav. Sci. 36:91-98. https://doi.org/10.1016/0168-1591(93)90001 -6 .

Jensen, M. B. 2011. The early behaviour of cow and calf in an individual calving pen. Appl. Anim. Behav. Sci. 134:92-99. https://doi .org/10.1016/j.applanim.2011.06.017.

Jensen, M. B. 2012. Behaviour around the time of calving in dairy cows. Appl. Anim. Behav. Sci. 139:195-202. https://doi.org/10 .1016/j.applanim.2012.04.002.

Johnsen, J. F., J. R. E. Johanssen, A. V. Aaby, S. G. Kischel, L. E. Ruud, A. Soki-Makilutila, T. B. Kristiansen, A. G. Wibe, K. E. Bøe, and S. Ferneborg. 2021. Investigating cow-calf contact in cow-driven systems: Behaviour of the dairy cow and calf. J. Dairy Res. 88:52-55. https://doi.org/10.1017/S0022029921000194.

Johnsen, J. F., H. Viljugrein, K. E. Bøe, S. M. Gulliksen, A. Beaver, A. M. Grøndahl, T. Sivertsen, and C. M. Mejdell. 2019. A crosssectional study of suckling calves' passive immunity and associations with management routines to ensure colostrum intake on organic dairy farms. Acta Vet. Scand. 61:7.

Johnsen, J. F., K. A. Zipp, T. Kälber, A. M. de Passillé, U. Knierim, K. Barth, and C. M. Mejdell. 2016. Is rearing calves with the dam a feasible option for dairy farms? - Current and future research. Appl. Anim. Behav. Sci. 181:1-11. https://doi.org/10.1016/j .applanim.2015.11.011.

Knierim, U., D. Wicklow, S. Ivemeyer, and D. Möller. 2020. A framework for the socio-economic evaluation of rearing systems of dairy calves with or without cow contact. J. Dairy Res. 87(S1):128-132. https://doi.org/10.1017/S0022029920000473.

Leruste, H., E. A. M. Bokkers, L. F. M. Heutinck, M. Wolthuis-Fillerup, J. T. N. Van Der Werf, M. Brscic, G. Cozzi, B. Engel, C. G. Van Reenen, and B. J. Lensink. 2012. Evaluation of onfarm veal calves' responses to unfamiliar humans and potential influencing factors. Animal 6:2003-2010. https://doi.org/10.1017/ S1751731112001346.

LIC and DairyNZ. 2020. New Zealand Dairy Statistics 2019-2020. Hamilton, New Zealand. Accessed Oct. 13, 2021. https://www .dairynz.co.nz/publications/dairy-industry/new-zealand-dairy -statistics-2019-20/.

Lidfors, L. M. 1996. Behavioural effects of separating the dairy calf immediately or 4 days post-partum. Appl. Anim. Behav. Sci. 49:269283. https://doi.org/10.1016/0168-1591(96)01053-2.

MacDonald, J. M., J. Law, and R. Mosheim. 2020. Consolidation in U.S. Dairy Farming, ERR-274, July 2020. USDA. Accessed Oct. 13, 2021. http://www.ers.usda.gov/webdocs/publications/98901/ err-274.pdf? $\mathrm{v}=5459$.

Meagher, R. K., A. Beaver, D. M. Weary, and M. A. G. von Keyserlingk. 2019. Invited review: A systematic review of the effects of prolonged cow-calf contact on behavior, welfare, and productivity. J. Dairy Sci. 102:5765-5783. https://doi.org/10.3168/jds.2018 $-16021$.

Nehring, R., J. Sauer, J. Gillespie, and C. Hallahan. 2016. United States and European Union dairy farms: Where is the competitive edge? Int. Food Agribus. Manag. Assoc. 19:219-240. https://ifama .org/resources/Documents/v19ib/1320150192.pdf.

Pempek, J. A., G. M. Schuenemann, E. Holder, and G. G. Habing. 2017. Dairy calf management-A comparison of practices and producer attitudes among conventional and organic herds. J. Dairy Sci. 100:8310-8321. https://doi.org/10.3168/jds.2017-12565.

Placzek, M., I. Christoph-Schulz, and K. Barth. 2021. Public attitude towards cow-calf separation and other common practices of calf rearing in dairy farming - A review. Org. Agric. 11:41-50. https:// doi.org/10.1007/s13165-020-00321-3.

Robbins, J. A., D. M. Weary, C. A. Schuppli, and M. A. G. Von Keyserlingk. 2015. Stakeholder views on treating pain due to dehorning dairy calves. Anim. Welf. 24:399-406. https://doi.org/10.7120/ 09627286.24.4.399.

Roche, S. M., A. Jones-Bitton, M. Meehan, M. Von Massow, and D. F. Kelton. 2015. Evaluating the effect of Focus Farms on Ontario dairy producers' knowledge, attitudes, and behavior toward control of Johne's disease. J. Dairy Sci. 98:5222-5240. https://doi .org/10.3168/jds.2014-8765.

Saunders, B., J. Sim, T. Kingstone, S. Baker, J. Waterfield, B. Bartlam, H. Burroughs, and C. Jinks. 2018. Saturation in qualitative research: Exploring its conceptualization and operationalization. Qual. Quant. 52:1893-1907. https://doi.org/10.1007/s11135 $-017-0574-8$

Schuppli, C. A., M. A. G. von Keyserlingk, and D. M. Weary. 2014. Access to pasture for dairy cows: Responses from an online engagement. J. Anim. Sci. 92:5185-5192. https://doi.org/10.2527/ jas.2014-7725.

Scrinis, G., C. Parker, and R. Carey. 2017. The caged chicken or the free-range egg? the regulatory and market dynamics of layer-hen welfare in the UK, Australia and the USA. J. Agric. Environ. Ethics 30:783-808. https://doi.org/10.1007/s10806-017-9699-y.

Shields, S., P. Shapiro, and A. Rowan. 2017. A decade of progress toward ending the intensive confinement of farm animals in the United States. Animals (Basel) 7:40. https://doi.org/10.3390/ ani7050040.

Shivley, C. B., J. E. Lombard, N. J. Urie, C. A. Kopral, M. Santin, T. J. Earleywine, J. D. Olson, and F. B. Garry. 2018. Preweaned heifer management on US dairy operations: Part VI. Factors asso- 
ciated with average daily gain in preweaned dairy heifer calves. J. Dairy Sci. 101:9245-9258. https://doi.org/10.3168/jds.2017-14022.

Sumner, C. L., and M. A. G. von Keyserlingk. 2018. Canadian dairy cattle veterinarian perspectives on calf welfare. J. Dairy Sci. 101:10303-10316. https://doi.org/10.3168/jds.2018-14859.

Sumner, C. L., M. A. G. von Keyserlingk, and D. M. Weary. 2018. How benchmarking motivates farmers to improve dairy calf management. J. Dairy Sci. 101:3323-3333. https://doi.org/10.3168/jds 2017-13596.

Thomas, G. W., S. A. Spiker, and F. J. Mickan. 1981. Influence of suckling by Friesian cows on milk production and anoestrus. Aust. J. Exp. Agric. 21:5-11. https://doi.org/10.1071/EA9810005.

Urie, N. J., J. E. Lombard, C. B. Shivley, C. A. Kopral, A. E. Adams, T. J. Earleywine, J. D. Olson, and F. B. Garry. 2018. Preweaned heifer management on US dairy operations: Part V. Factors associated with morbidity and mortality in preweaned dairy heifer calves. J. Dairy Sci. 101:9229-9244. https://doi.org/10.3168/jds .2017-14019.

Vaarst, M., F. Hellec, C. Verwer, J. R. E. Johanssen, and K. Sørheim. 2020. Cow calf contact in dairy herds viewed from the perspectives of calves, cows, humans and the farming system. Farmers ' perceptions and experiences related to dam-rearing systems. J. Sustain. Org. Agric. Syst. 70:49-57. https://doi.org/10.3220/ LBF1596195636000.

Vaarst, M., T. B. Nissen, S. Østergaard, I. C. Klaas, T. W. Bennedsgaard, and J. Christensen. 2007. Danish stable schools for experiential common learning in groups of organic dairy farmers. J. Dairy Sci. 90:2543-2554. https://doi.org/10.3168/jds.2006-607.

Veissier, I., A. Butterworth, B. Bock, and E. Roe. 2008. European approaches to ensure good animal welfare. Appl. Anim. Behav. Sci. 113:279-297. https://doi.org/10.1016/j.applanim.2008.01.008.

Ventura, B. A., M. A. G. von Keyserlingk, C. A. Schuppli, and D. M. Weary. 2013. Views on contentious practices in dairy farming: The case of early cow-calf separation. J. Dairy Sci. 96:6105-6116. https: //doi.org/10.3168/jds.2012-6040.
Ventura, B. A., M. A. G. von Keyserlingk, H. Wittman, and D. M. Weary. 2016. What difference does a visit make? Changes in animal welfare perceptions after interested citizens tour a dairy farm. PLoS One 11:e0154733. https://doi.org/10.1371/journal.pone .0154733 .

von Keyserlingk, M. A. G., N. P. Martin, E. Kebreab, K. F. Knowlton, R. J. Grant, M. Stephenson, C. J. Sniffen, J. P. Harner III, A. D. Wright, and S. I. Smith. 2013. Invited review: Sustainability of the US dairy industry. J. Dairy Sci. 96:5405-5425. https://doi.org/10 $.3168 /$ jds.2012-6354.

Weary, D. M., and B. Chua. 2000. Effects of early separation on the dairy cow and calf: 1 . Separation at $6 \mathrm{~h}, 1$ day and 4 days after birth. Appl. Anim. Behav. Sci. 69:177-188. https://doi.org/10 .1016/S0168-1591(00)00128-3.

Weary, D.M., B.A. Ventura, and M.A.G. von Keyserlingk. 2016. Societal views and animal welfare science: understanding why the modified cage may fail and other stories. 10:309-317. https://doi .org/10.1017/S1751731115001160.

Wenker, M. L., E. A. M. Bokkers, and B. Lecorps. M. A. G. von Keyserlingk C. G. van Reenen, C. M. Verwer, and D. M. Weary. 2020. Effect of cow-calf contact on cow motivation to reunite with their calf. Sci. Rep. 10:14233. https://doi.org/10.1038/s41598-020 -70927-w.

Whay, H. R., and D. C. J. Main. 2010. Improving animal welfare: Practical approaches for achieving change. CABI Publishing.

\section{ORCIDS}

Heather W. Neave $\odot$ https://orcid.org/0000-0002-1818-8131 Christine L. Sumner () https://orcid.org/0000-0002-7400-910X

Roxanne J. T. Henwood ๑ https://orcid.org/0000-0003-4618-3618

Gosia Zobel ๑ https://orcid.org/0000-0002-9883-9503

James R. Webster ๑ https://orcid.org/0000-0002-2240-4714 